Asian J. Med. Biol. Res. 2020, 6 (2), 340-350; doi: 10.3329/ajmbr.v6i2.48082

\author{
Asian Journal of \\ Medical and Biological Research \\ ISSN 2411-4472 (Print) 2412-5571 (Online) \\ www.ebupress.com/journal/ajmbr
}

Article

\title{
A cross sectional study on clinical trends of reproductive performances and reproductive disorders of dairy cows in Rajshahi district of Bangladesh
}

\author{
Rashida Khaton $^{1 *}$, Md. Abul Hasnat ${ }^{2}$, Md. Royhan Gofur ${ }^{1}$, Md. Zakir Hossain ${ }^{1}$, Md Alauddin ${ }^{1}$ and Md. Jalal \\ Uddin Sarder ${ }^{1}$ \\ ${ }^{1}$ Department of Veterinary and Animal Sciences, University of Rajshahi, Rajshahi, Bangladesh \\ ${ }^{2}$ Ex Research Investigator, ICDDR’B, Bangladesh \\ *Corresponding Author: Dr. Rashida Khaton, Veterinary and Animal Sciences Department, Faculty of \\ Agriculture, University of Rajshahi, Rajshahi-6205, Bangladesh. Phone: +88-0721-711141 (Office); E-mail: \\ rashidavet@yahoo.com
}

Received: 03 June 2020/Accepted: 28 June 2020/ Published: 30 June 2020

\begin{abstract}
Performance evaluation of existing dairying is important to design relevant dairy development strategies and implement context specific interventions for future development of the dairy enterprise. The present study was carried out to evaluate the clinical trends (reproductive performance and disorders) of dairy cows of Rajshahi district, Bangladesh. A total of 500 cows randomly selected and data were collected directly from the dairy farms owners from 6 upazilas and 4 metro thanas of Rajshahi district by using questionnaires and diagnosis of reproductive disorders (RD) was made on the basis of history, clinical signs and response to treatment. The average reproductive performance (RP) were recorded as age at puberty $26.42 \pm 0.22 \mathrm{~m}$, age at first calving $35.48 \pm 0.22 \mathrm{~m}$, post-partum heat period $121.85 \pm 3.48$ days, service per conception $1.93 \pm 0.04$, days open 136.80 \pm 3.57 days and calving interval 401.04 \pm 3.94 days. The better RP was found at metro thanas compared to upazilas, though no significant difference was found except on service per conception $(\mathrm{p}<0.05)$. The overall prevalence of RD was $78.6 \%$ in Rajshahi district. Among the reproductive and productive disorders, anoestrus $24.6 \%$ was the highest prevalent disorders followed by abortion $13.4 \%$, repeat breeding $11.4 \%$, retained placenta $10.2 \%$, dystocia $5.4 \%$, mastitis $4.4 \%$, vaginal prolapse $2.4 \%$, pyometra $1.8 \%$, metritis $1.6 \%$, uterine prolapse $1.4 \%$, milk fever $1.2 \%$ and still birth $0.8 \%$. The highest occurrence of RD was recorded in Tanore upazila (92\%) and the lowest in Poba upazila (62\%). In comparison between the upazila and metro thanas the minimum occurrence of RD was recorded in metro thanas (31\%) than upazilas $(47.6 \%)$.
\end{abstract}

Keywords: clinical trends; dairy cow; upazila; metro thana; Rajshahi district

\section{Introduction}

Livestock, an integral part of agriculture, plays an important role to keep the rural economy of Bangladesh viable (Sarma and Ahmed, 2011). The contribution of the livestock sector to overall GDP has been provisionally estimated at $1.78 \%$ for 2013-14 (BER, 2014) and its share of agricultural GDP in 2013-14 was 14.08\% (provisionally estimated). Despite its modest share of overall GDP, livestock serves an essential role as a source of protein, employment generation, export earning, and provision of food security. Livestock resources play an important role in the sustenance of landless people, livelihood options for the rural poor families and are potentially important for poverty reduction (FAO, 2009). The importance of livestock production has increased in Bangladesh as witnessed by the growth of the sub-sector over the last few decades in Bangladesh (FAO, 2005). The urban and rural society of Bangladesh has long been enjoying the contribution of livestock for meeting the demand. Agriculture, including livestock and fisheries, has emerged as a growth driver in the 21 st century. The potential of the livestock sub-sector is much higher than generally estimated at present. Among the livestock, cattle are most available and versatile component providing a significant contribution to gross domestic, export products and raw materials for industries in relation to existing integrated 
agricultural farming system in Bangladesh. So, livestock sector in Bangladesh alongside agriculture is considered as the backbone of Bangladesh economy (Ahmed et al., 2013). On the other hand, Bangladesh is a developing country where about $70 \%$ people live in the rural areas (MoEF, 2009). There is no doubt that most of the people live in the countryside somehow depend on agriculture either livestock or fisheries. Rural people are likely more engage themselves in livestock farming for their livelihoods. To improve the productivity of livestock, the government has adopted the National Livestock Development Policy (NLDP) 2007. The policy identified ten critical areas for policy issues and dairy development is one of them. The main goal of dairy farmers is one calf/cow per year. The livestock population in Bangladesh is currently estimated to comprise 25.7 million cattle, 0.83 million buffaloes, 14.8 million goats, 1.9 million sheep, 118.7 million chicken and 34.1 million ducks (http://en.banglapedia.org/ index.php? title=Livestock) and the cattle population in Rajshahi district is approximately 5.35 lakh (personal contact with DLS, Rajshahi; 2015).

The urban and peri-urban dairy production has been developed in response to the fast growing demand for milk and milk products. During the past few decades, rapidly increasing urban population has created better markets and growth of demand for dairy products (Weldeslasse et al., 2012). This situation creates an opportunity and potential for development of milk production and processing industry in urban and peri-urban areas. Urban and peri-urban/rural dairy production systems are emerging as an important component of the milk production system. This system is contributing immensely towards filling in the large demand-supply gap for milk and milk products in urban centers of any country, where consumption of milk and milk products is remarkably high (Azage and Alemu, 1998; Mureda and Zeleke, 2008).

Sound health, reproduction and production i.e. calf and milk production are the principal factors affecting the profitability of a dairy herd. In recent years, the dairy industry agenda in many countries has been dominated by health-related problems (Vacek et al., 2007). The lifetime productivity of cows largely depends on their individual reproductive performance such as age at puberty, age at first calving and calving interval (Ensminger, 1969). The best cows are clearly those that have their first calf at an early age, have minimum calving intervals, and live a long time (Carew et al., 1986). Thus, the most important measures of reproductive performance of cows are age at first calving, length of calving interval and length of cow productive life. The current level of reproductive performance in dairy herds is well below the optimum in most countries (Morton, 2003). Reproductive inefficiency in turn, however, affects dairy herd profitability by decreasing milk yield, the number of replacement heifers produced and by increasing culling rate (Grohn and Rajwala, 2000; Santos, 2007).

Reproductive and production disorders of dairy cattle significantly reduce their productivity which is of great concern of dairy producers worldwide because most reproductive disorders adversely affect the future fertility. Poor reproductive performance is a crucial production of limiting issue. It has been reportable that reproductive disorders are accountable exceptional economic losses to the dairy farmers in Bangladesh (Talukder et al., 2005). In European and American dairy herds, about a third of all cows are culled because of reproductive disturbances (Faruq, 2001). The occurrence of various reproductive disorders is increased in Bangladesh due to introduction of intensive cross breeding programme through artificial insemination (Faruq, 2001; Khair et al., 2013).

The occurrence of different reproductive disorders in cows has been reported in Bangladesh by several authors (Shamsuddin et al., 1988; Das et al., 1995). However, except in metro thanas and upazilas near to Rajshahi city, very little work has been done to identify the reproductive performance of dairy cows in Rajshahi district, especially situated in lowland and hilly areas. This has led to overlooking dairying at upazila level from incorporating into the country's research agenda and to the overall agricultural development program. Hence, in order to design relevant dairy development strategies and implement context specific interventions for future development of the dairying at both metro and upazila level, performance evaluation of existing dairying is important. The scientific information regarding the aforementioned parameters helps as a starting point for further development endeavors in dairy enterprise in the nation. Therefore, the present study was undertaken and designed with the objectives of identification of clinical trends (reproductive performance and reproductive disorders) of cows available in different Metro thanas and Upazillas of Rajshahi district of Bangladesh.

\section{Materials and Methods}

\subsection{Study areas and population}

The study was conducted at Rajshahi district in Bangladesh. The cows were selected from 6 upazilas viz. Charghat, Puthia, Poba, Godagari, Tanore, Mohanpur and 4 metro thanas were Motihar, Boalia, Rajpara, Shahmukdhm of Rajshahi district. Fifty cows were randomly selected from each upazila and metro thana for this study on a total of 500 dairy cows. 


\subsection{Method of data collection}

The data were collected directly from the dairy cows owners/farmers/attendant by using questionnaires and diagnosis of reproductive disorders were made on the basis of the history, clinical signs and response to treatment during the period from July 2013 to June 2015. The data were collected from the randomly selected farms by the researcher every three (3) months interval in year. After collecting the information, data were prepared for analysis.

\subsection{Reproductive traits of cows studied}

The following reproductive traits of dairy cows were studied in this study.

Age at puberty: The age at which a heifer first shows the estrous signs and behaviors may be defined as age at puberty. It was measured in month (m).

Age at first calving: It is defined as the age when a heifer first calving a newborn calf. It was measured in month $(\mathrm{m})$.

Post-partum heat period: It is considered as the interval between date of calving and the date of first insemination or first heat show after parturition. It was calculated in days (d).

Service per conception: The average number of services or inseminations required for each successful conception in case of heifer and cows.

Days open: Days open was measured in days. Day's open is referred as interval from parturition to date of conception of cows.

Calving interval: The number of days between two successful calving of the same cows or the period from one calving to the next was termed as calving interval. It was measured in days.

\subsection{Definition of recorded diseases taken mostly from Sarder et al. (2010)}

Abortion: Abortion is a condition in which the foetus is delivered live or dead before reaching the stage of viability and in which the delivered foetus is generally visible by naked eyes.

Anoestrus: Lack of expression of the oestrus at an expected time is called anoestrus. Clinically if a heifer is 18 or more months old or a cow has passed (40-60) days post-partum but did not show oestrus the condition is referred as anoestrus.

Metritis: Metritis is the inflammation of the uterus generally caused by infectious agents. Usually cows have red to brown discharge during the first two weeks after calving. If discharge persists beyond two weeks or if the discharge is foul smelling, this is an evidence of metritis.

Mastitis: The term mastitis refers to inflammation of the mammary gland regardless of the cause. It is characterized by physical, chemical and usually bacteriological changes in the milk and by pathological changes in the gland (Radostits et al., 2006). Diagnosis of mastitis was based on history, physical abnormalities of udder and gross abnormalities in the milk like discoloration and presence of clots/flakes. Palpation of udder revealed enlarged and painful with the presence of clots/ flakes in the milk confirmed the diagnosis of mastitis.

Retained placenta: A cow was considered to have retained placenta when the foetal membranes were visible at the vulva or were identified in the uterus or vagina by vaginal examination more than $24 \mathrm{hrs}$ after calving.

Repeat breeders: Cows failing to conceive after a defined number of inseminations (generally three or more) with fertile semen, have been classified as repeat breeders (Levine, 1999).

\subsection{Data management and analysis}

The data obtained from the questionnaire was entered into the Microsoft Excel 2007 and transferred to SPSS version 17. Data were statistically analyzed to estimates the clinical trends of reproductive performances and reproductive disorders of dairy cows. Various standard statistical procedures (percentages, mean and chi-square test etc.) had been adopted in this study. Mean of different traits were then tested by using Analysis of Variance (ANOVA) by Duncan Multiple Range Test (DMRT). Descriptive statistics was done to explore the clinical trends of reproductive disorders of cows at Rajshahi district. Data were presented as Mean \pm SE. P $<0.05$ was considered as significant.

\section{Results}

\subsection{The reproductive performance of dairy cows in different upazilas and metro thanas}

The reproductive performance of dairy cows in different upazilas and metro thanas of Rajshahi district were presented in Table 1 and we found significant $(\mathrm{p}<0.05)$ difference in reproductive performance of dairy cows among different upazilas and metro thanas. The highest age at puberty $(28.46 \pm 0.55 \mathrm{~m})$ and age at first calving $(37.39 \pm 0.57 \mathrm{~m})$ were observed in Godagari upazila whereas the lowest $(24.52 \pm 0.71 \mathrm{~m})$ and $(33.54 \pm 0.69 \mathrm{~m})$ 
in Boalia metro thana. The lowest value of post-partum heat period $(92.08 \pm 5.3 \mathrm{~d})$ was obtained in Rajpara metro thana and the highest value $(148.82 \pm 11.45 \mathrm{~d})$ was in Godagari upazila. The lowest service per conception $(1.62 \pm 0.11)$ was observed in Boalia thana and the highest $(2.46 \pm 0.13)$ was in Mohanpur upazila. The highest value of days open and calving interval $(158.82 \pm 11.41 \mathrm{~d}$ and $422.31 \pm 12.34 \mathrm{~d})$ were observed in Godagari upazila and the lowest values $(115.13 \pm 6.82$ d) were in Rajpara and $(373.46 \pm 12.88$ d) was in Poba upazila, respectively.

Table 1. Reproductive performance of dairy cows in different Upazilas and Metro thanas.

\begin{tabular}{|c|c|c|c|c|c|c|}
\hline \multirow{2}{*}{$\begin{array}{l}\text { Name of } \\
\text { upazilas and } \\
\text { metro thanas }\end{array}$} & \multicolumn{6}{|c|}{ Reproductive performances } \\
\hline & $\begin{array}{l}\text { Age at puberty } \\
\text { (m) }\end{array}$ & $\begin{array}{l}\text { Age at 1 }{ }^{\text {st }} \\
\text { calving (m) }\end{array}$ & $\begin{array}{l}\text { Post-partum heat } \\
\text { period (d) }\end{array}$ & $\begin{array}{l}\text { Service/ } \\
\text { conception }\end{array}$ & Days open (d) & $\begin{array}{l}\text { Calving interval } \\
\text { (d) }\end{array}$ \\
\hline Charghat & $\begin{array}{l}27.28 \pm 0.59^{a b} \\
(n=50)\end{array}$ & $\begin{array}{l}36.08 \pm 0.63^{\mathrm{abc}} \\
(\mathrm{n}=46)\end{array}$ & $\begin{array}{l}142.74 \pm 8.14^{\mathrm{ab}} \\
(\mathrm{n}=35)\end{array}$ & $\begin{array}{l}2.20 \pm 0.12^{\mathrm{ab}} \\
(\mathrm{n}=50)\end{array}$ & $\begin{array}{l}151.2 \pm 8.30^{\mathrm{ab}} \\
(\mathrm{n}=35)\end{array}$ & $\begin{array}{l}420.64 \pm 11.27^{\mathrm{a}} \\
(\mathrm{n}=25)\end{array}$ \\
\hline Puthia & $\begin{array}{l}27.06 \pm 0.70^{\mathrm{ab}} \\
\mathrm{n}=50)\end{array}$ & & & & $\begin{array}{l}152.79 \pm 13.93^{\mathrm{a}} \\
(\mathrm{n}=39)\end{array}$ & $\begin{array}{l}415.56 \pm 14.92^{\mathrm{a}} \\
(\mathrm{n}=32)\end{array}$ \\
\hline Poba & $\begin{array}{l}25.70 \pm 0.80^{\text {bcd }} \\
(\mathrm{n}=50)\end{array}$ & $\begin{array}{l}35.13 \pm 0.76^{\mathrm{bcd}} \\
(\mathrm{n}=46)\end{array}$ & $\begin{array}{l}125.40 \pm 11.30^{\mathrm{abc}} \\
(\mathrm{n}=45)\end{array}$ & $\begin{array}{l}2.22 \pm 0.20^{\mathrm{ab}} \\
(\mathrm{n}=50)\end{array}$ & $\begin{array}{l}129.33 \pm 13.87^{\mathrm{ab}} \\
(\mathrm{n}=39)\end{array}$ & $\begin{array}{l}373.46 \pm 12.88^{b} \\
(n=32)\end{array}$ \\
\hline God & $\begin{array}{l}28.4 \\
(\mathrm{n}=5\end{array}$ & $\begin{array}{l}37.39 \pm 0.57^{\mathrm{a}} \\
(\mathrm{n}=48)\end{array}$ & $\begin{array}{l}148.82 \pm 11.45^{\mathrm{a}} \\
(\mathrm{n}=46)\end{array}$ & $\begin{array}{l}1.82 \pm 0.12^{\mathrm{bc}} \\
(\mathrm{n}=50)\end{array}$ & $\begin{array}{l}158.82 \pm 11.41^{\mathrm{a}} \\
(\mathrm{n}=46)\end{array}$ & $\begin{array}{l}422.31 \pm 12.34^{\mathrm{a}} \\
(\mathrm{n}=38)\end{array}$ \\
\hline Tanore & $0.73^{\text {cd }}$ & $\begin{array}{l}33.95 \pm 0.74^{\mathrm{cd}} \\
(\mathrm{n}=49)\end{array}$ & $\begin{array}{l}111.50 \pm 8.00^{\mathrm{bc}} \\
(\mathrm{n}=46)\end{array}$ & $0.12^{\mathrm{bc}}$ & $\begin{array}{l}130.20 \pm 8.78^{\mathrm{ab}} \\
(\mathrm{n}=45)\end{array}$ & $\begin{array}{l}401.81 \pm 8.83^{\text {bc }} \\
(\mathrm{n}=43)\end{array}$ \\
\hline Moha & $\begin{array}{l}26.06 \pm 0.71^{\text {bcd }} \\
(\mathrm{n}=50)\end{array}$ & $\begin{array}{l}35.08 \pm 0.73^{\mathrm{bcd}} \\
(\mathrm{n}=49)\end{array}$ & $\begin{array}{l}123.41 \pm 15.18^{\mathrm{abc}} \\
(\mathrm{n}=46)\end{array}$ & $\begin{array}{l}2.46 \pm 0.13^{\mathrm{a}} \\
(\mathrm{n}=50)\end{array}$ & $\begin{array}{l}134.32 \pm 14.85^{a b} \\
(n=46)\end{array}$ & $\begin{array}{l}400.55 \pm 17.73^{b c} \\
(n=38)\end{array}$ \\
\hline Moti & $\begin{array}{l}26.92 \pm 0.66^{\mathrm{abc}} \\
(\mathrm{n}=50)\end{array}$ & $\begin{array}{l}35.85 \pm 0.68^{\mathrm{abc}} \\
(\mathrm{n}=49)\end{array}$ & $\begin{array}{l}117.27 \pm 9.85^{\mathrm{abc}} \\
(\mathrm{n}=44)\end{array}$ & $\begin{array}{l}1.94 \pm 0.11^{\mathrm{bc}} \\
(\mathrm{n}=50)\end{array}$ & $\begin{array}{l}127.70 \pm 10.43^{\mathrm{ab}} \\
(\mathrm{n}=41)\end{array}$ & $\begin{array}{l}389.93 \pm 12.25^{\mathrm{bc}} \\
(\mathrm{n}=29)\end{array}$ \\
\hline Boalia & $\begin{array}{l}24.52 \pm 0.71^{\mathrm{d}} \\
(\mathrm{n}=50)\end{array}$ & $\begin{array}{l}33.54 \pm 0.69^{d} \\
(n=48)\end{array}$ & $\begin{array}{l}110.71 \pm 13.38^{\mathrm{bc}} \\
(\mathrm{n}=42)\end{array}$ & $\begin{array}{l}1.62 \pm 0.11^{\mathrm{c}} \\
(\mathrm{n}=50)\end{array}$ & $\begin{array}{l}130.02 \pm 10.78^{a b} \\
(n=44)\end{array}$ & $\begin{array}{l}394.10 \pm 11.22^{\mathrm{bc}} \\
(\mathrm{n}=37)\end{array}$ \\
\hline Rajpara & $\begin{array}{l}27.22 \pm 0.34^{\mathrm{ab}} \\
(\mathrm{n}=50)\end{array}$ & $\begin{array}{l}36.22 \pm 0.34^{\mathrm{ab}} \\
(\mathrm{n}=50)\end{array}$ & $\begin{array}{l}92.08 \pm 5.3^{\mathrm{c}} \\
(\mathrm{n}=46)\end{array}$ & $\begin{array}{l}1.76 \pm 0.14^{\mathrm{c}} \\
(\mathrm{n}=50)\end{array}$ & $\begin{array}{l}115.13 \pm 6.82^{b} \\
(\mathrm{n}=46)\end{array}$ & $\begin{array}{l}382.71 \pm 8.06^{b c} \\
(n=35)\end{array}$ \\
\hline Shahmukdhm & $\begin{array}{l}26.12 \pm 0.94^{\text {bcd }} \\
(\mathrm{n}=50)\end{array}$ & $\begin{array}{l}35.14 \pm 0.96^{\text {bcd }} \\
(\mathrm{n}=49)\end{array}$ & $\begin{array}{l}125.85 \pm 9.26^{\mathrm{abc}} \\
(\mathrm{n}=41)\end{array}$ & $\begin{array}{l}1.66 \pm 0.15^{\mathrm{c}} \\
(\mathrm{n}=50)\end{array}$ & $\begin{array}{l}142.52 \pm 9.91^{\mathrm{ab}} \\
(\mathrm{n}=40)\end{array}$ & $\begin{array}{l}410.13 \pm 10.65^{b c} \\
(n=36)\end{array}$ \\
\hline & $\begin{array}{l}26.42 \pm 0.22 \\
(\mathrm{n}=500)\end{array}$ & $\begin{array}{l}35.48 \pm 0.22 \\
(\mathrm{n}=482)\end{array}$ & $\begin{array}{l}121.85 \pm 3.48 \\
(\mathrm{n}=432)\end{array}$ & $\begin{array}{l}1.93 \pm 0.04 \\
(\mathrm{n}=500)\end{array}$ & $\begin{array}{l}136.80 \pm 3.57 \\
(\mathrm{n}=421)\end{array}$ & $\begin{array}{l}401.04 \pm 3.94 \\
(\mathrm{n}=345)\end{array}$ \\
\hline
\end{tabular}

$\mathrm{m}=$ months, $d=$ days; superscripts $(\mathrm{a}, \mathrm{b}, \mathrm{c}, \mathrm{d})$ in the same column differs significantly with each other $(\mathrm{p}<0.05)$.

A comparative scenario between the reproductive performance of dairy cows of upazilas and metro thanas of Rajshahi district were presented in Table 2. The higher value of age at puberty, age at first calving, post-partum heat period, service per conception, days open and calving interval was observed in upazilas compared to metro thanas. A significant $(\mathrm{p}<0.05)$ difference was found only on service per conception between dairy cows of upazila and metro thanas and other reproductive traits were not significant $(p>0.05)$.

Table 2. The comparative scenario of reproductive performances of dairy cows between Upazilas and Metro thanas.

\begin{tabular}{|c|c|c|c|c|c|c|c|c|}
\hline \multirow{2}{*}{$\begin{array}{l}\text { Reproductive } \\
\text { parameters }\end{array}$} & \multicolumn{2}{|c|}{ Name of upazilas and metro thanas } & \multirow[b]{2}{*}{ Grand total } & \multirow{2}{*}{$\begin{array}{l}\text { Chi- } \\
\text { Square }\end{array}$} & \multirow{2}{*}{ C.V } & \multirow{2}{*}{ T.V } & \multirow{2}{*}{ D.F } & \multirow{2}{*}{ Significance } \\
\hline & Upazila & Metro thana & & & & & & \\
\hline Age at puberty $(\mathrm{m})$ & $\begin{array}{l}26.57 \pm 0.28 \\
(\mathrm{n}=300)\end{array}$ & $\begin{array}{l}26.19 \pm 0.35 \\
(\mathrm{n}=200)\end{array}$ & $\begin{array}{l}26.42 \pm 0.22 \\
(\mathrm{n}=500)\end{array}$ & \multirow{6}{*}{$\chi^{2}$} & 38.91 & 41.33 & 28 & NS \\
\hline $\begin{array}{l}\text { Age at } 1^{\text {st }} \text { calving } \\
(\mathrm{m})\end{array}$ & $\begin{array}{l}35.67 \pm 0.28 \\
(\mathrm{n}=286)\end{array}$ & $\begin{array}{l}35.20 \pm 0.35 \\
(\mathrm{n}=196)\end{array}$ & $\begin{array}{l}35.48 \pm 0.22 \\
(\mathrm{n}=482)\end{array}$ & & 33.83 & 38.89 & 26 & NS \\
\hline $\begin{array}{l}\text { Post-partum heat } \\
\text { period (d) }\end{array}$ & $\begin{array}{l}126.73 \pm 4.9 \\
(\mathrm{n}=256)\end{array}$ & $\begin{array}{l}114.76 \pm 4.66 \\
(\mathrm{n}=176)\end{array}$ & $\begin{array}{l}121.85 \pm 3.48 \\
(\mathrm{n}=432)\end{array}$ & & 33.90 & 52.19 & 37 & NS \\
\hline $\begin{array}{l}\text { Service per } \\
\text { conception }\end{array}$ & $\begin{array}{l}2.06 \pm .06 \\
(\mathrm{n}=300)\end{array}$ & $\begin{array}{l}1.74 \pm .06 \\
(\mathrm{n}=200)\end{array}$ & $\begin{array}{l}1.93 \pm .04 \\
(\mathrm{n}=500)\end{array}$ & & 13.71 & 11.07 & 5 & * \\
\hline Days open (d) & $\begin{array}{l}142.56 \pm 5.02 \\
(\mathrm{n}=250)\end{array}$ & $\begin{array}{l}128.38 \pm 4.78 \\
(\mathrm{n}=171)\end{array}$ & $\begin{array}{l}136.80 \pm 3.57 \\
(\mathrm{n}=421)\end{array}$ & & 96.60 & 108.64 & 86 & NS \\
\hline Calving interval (d) & $\begin{array}{l}405.34 \pm 5.52 \\
(\mathrm{n}=208)\end{array}$ & $\begin{array}{l}394.52 \pm 5.30 \\
(\mathrm{n}=137)\end{array}$ & $\begin{array}{l}401.04 \pm 3.94 \\
(\mathrm{n}=345)\end{array}$ & & 78.57 & 88.25 & 68 & NS \\
\hline
\end{tabular}

$\chi^{2}=$ Chi-Square, $m=$ months, $d=$ days, C.V= Calculated value, T.V= Tabulated value, D.F= Degree of freedom, NS=Nonsignificant, $* \mathrm{p}<0.05$ 


\subsection{Reproductive status of dairy cows in Rajshahi disrtrict of Bangladesh}

The overall reproductive status of dairy cows at study area was presented in Figure 1. Around $78 \%$ cows were found affected with one of the studied reproductive disorders.

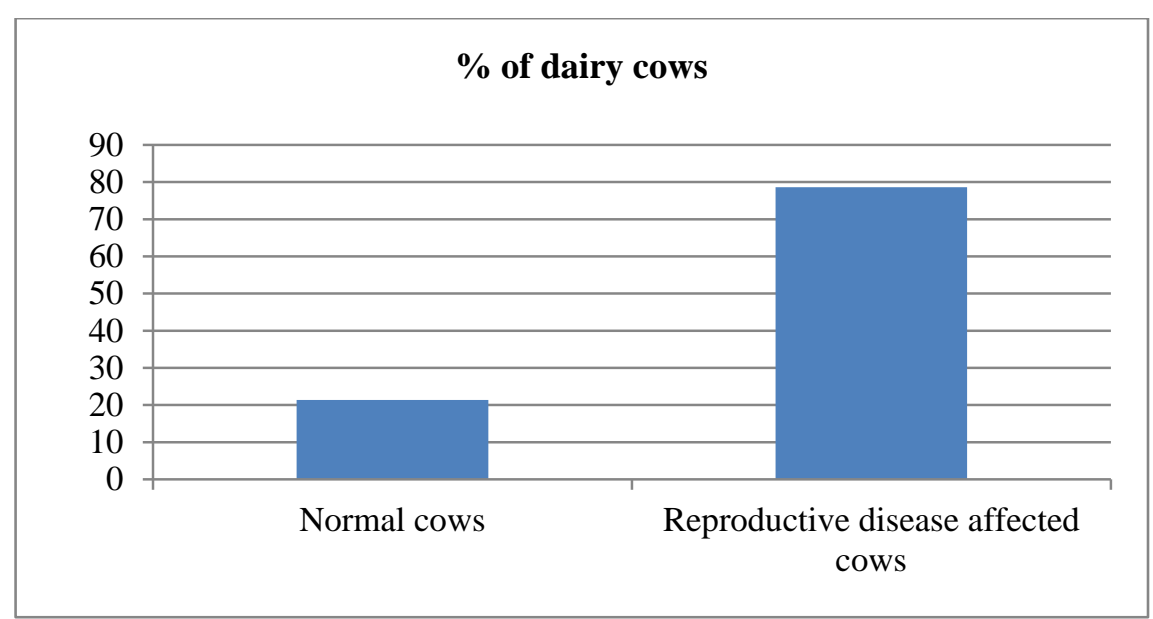

Figure 1. Reproductive status of dairy cows in Rajshahi district.

\subsection{The prevalence of various reproductive and productive disorders of dairy cows}

The prevalence of various reproductive and productive disorders of dairy cows was presented in Figure 2. Anoestrus was the highest prevalent disorder in Rajshahi district which was $24.6 \%$ followed by abortion, repeat breeding, retained placenta, dystocia, mastitis, vaginal prolapse, pyometra, metritis, uterine prolapse, milk fever and still birth.

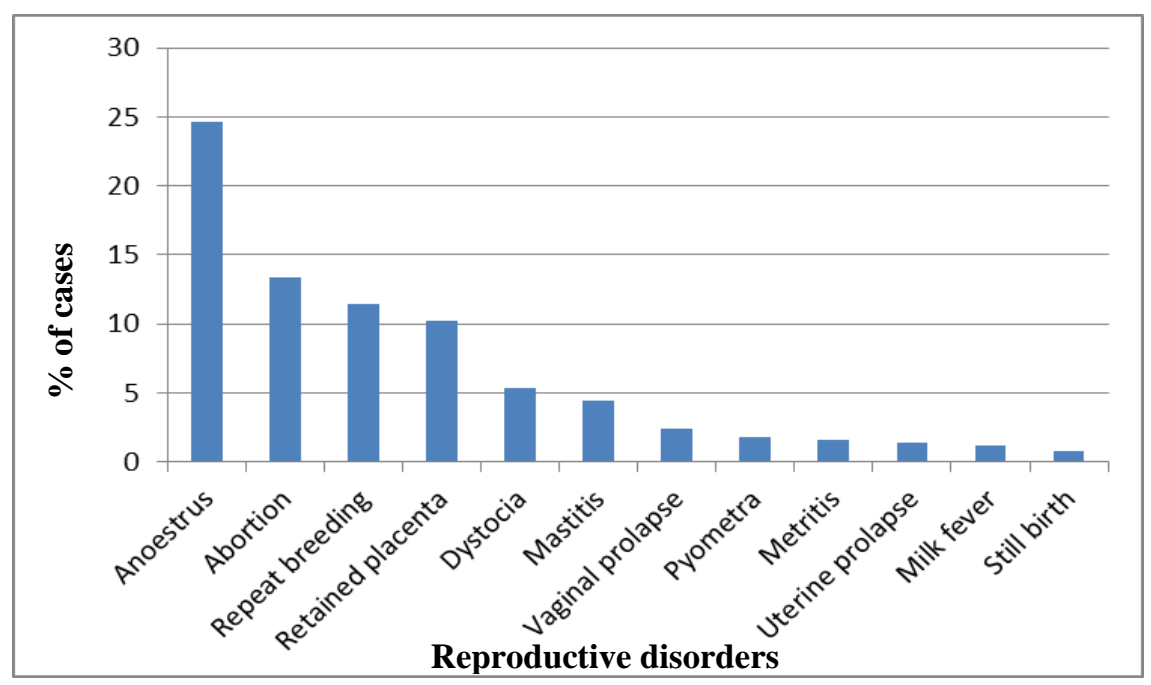

Figure 2. Prevalence of various reproductive and productive disorders of dairy cows $(n=500)$.

3.4. The prevalence of reproductive and productive disorders of dairy cows in different upazilas and metro thanas

The prevalence of reproductive and productive disorders of dairy cows in different Upazilas and Metro thanas was presented in Figure 3. The highest prevalence of reproductive disorders was in Tanor upazila whereas the lowest prevalence in Poba upazila. 


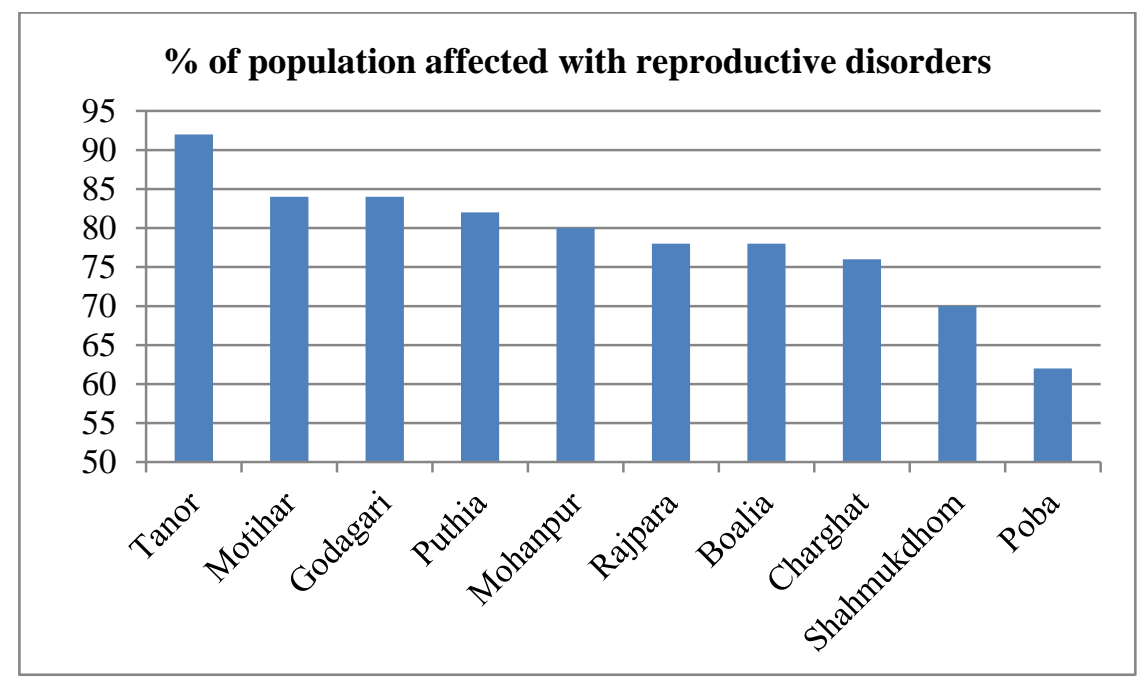

Figure 3. Prevalence of reproductive disorders of dairy cows in different upazilas and metro thanas.

3.5. Comparison of the prevalence of reproductive and productive disorders of dairy cows in between upazilas and metro thanas

The prevalence of reproductive and productive disorders of dairy cows in between upazilas and metro thanas was summarized in Table 3. The overall prevalence of reproductive disorders was comparatively higher in upazilas (47.6\%) than metro thanas (31\%). All of the studied disorders recorded with higher prevalence in upazilas than metro thanas except the milk fever (equal) and dystocia (higher in metro thanas).

Table 3. A comparative scenario of prevalence of reproductive and productive disorders between Upazilas and Metro thanas in dairy cows $(n=500)$.

\begin{tabular}{|l|l|l|l|l|}
\hline \multirow{2}{*}{$\begin{array}{l}\text { Name of reproductive } \\
\text { disorders }\end{array}$} & \multicolumn{2}{|c|}{ Name of upazilas and metro thanas } & \multirow{2}{*}{ Total } & \multirow{2}{*}{ \% of cases } \\
\cline { 2 - 3 } & Upazila & Metro thana & & 13.4 \\
\hline Abortion & $35(7 \%)$ & $32(6.4 \%)$ & 67 & 10.2 \\
\hline Retained placenta & $29(5.8 \%)$ & $22(4.4 \%)$ & 51 & 5.4 \\
\hline Dystocia & $13(2.6 \%)$ & $14(2.8 \%)$ & 27 & 2.4 \\
\hline Vaginal prolapse & $6(1.2 \%)$ & $6(1.2 \%)$ & 12 & 1.4 \\
\hline Uterine prolapse & $4(0.8 \%)$ & $3(0.6 \%)$ & 7 & 1.6 \\
\hline Metritis & $5(1 \%)$ & $3(0.6 \%)$ & 8 & 1.8 \\
\hline Pyometra & $6(1.2 \%)$ & $3(0.6 \%)$ & 9 & 0.8 \\
\hline Still birth & $3(0.6 \%)$ & $1(0.2 \%)$ & 4 & 24.6 \\
\hline Anoestrus & $82(16.4 \%)$ & $41(8.2 \%)$ & 123 & 11.4 \\
\hline Repeat breeding & $39(7.8 \%)$ & $18(3.6 \%)$ & 57 & 4.4 \\
\hline Mastitis & $13(2.6 \%)$ & $9(1.8 \%)$ & 22 & 1.2 \\
\hline Milk fever & $3(0.6 \%)$ & $3(0.6 \%)$ & 6 & 78.6 \\
\hline Grand Total & $238(47.6 \%)$ & $155(31 \%)$ & 393 & \\
\hline
\end{tabular}

\section{Discussion}

\subsection{Reproductive performance of dairy cows in Rajshahi district of Bangladesh}

Infertility problems that usually overlooked by the farmers, imbalance and undernourished feed management of dairy cows and calves, unavailability of pasture land, inadequate veterinary services, and unawareness of farmers in herd health management are the burning issues, which seriously affects the farm economy in Bangladesh (Shamsuddin et al., 2001). In the present study, we found significant $(\mathrm{p}<0.05)$ difference on reproductive parameters among metro thanas and upazilas of Rajshahi district. The highest age at puberty of this study was similar to the result of Nahar et al. (1992) where the age at puberty was 28.46 months. Sarder (2001) recorded age at first calving in 38.7 months and $411.3 \pm 122.7$ days calving interval was observed by Hoque et al. (1999) which were similar with the present study. On the other hand, similar to our study, Hossain (2013) studied to evaluate the reproductive performances of dairy cows at different upazila in Sylhet district, Bangladesh and found significant $(\mathrm{p}<0.05)$ difference on reproductive parameters among dairy cows of 
different upazilas. The highest age at puberty and age at first calving of cows in month $(28.7 \pm 6.5)$ and (41.5 $\pm 6.3)$ were observed in Biswanath upazila and the lowest in Golapgong upazila and Sylhet $(26.0 \pm 5.5)$ and $(38.0 \pm 5.7)$, respectively $(\mathrm{p}<0.05)$. The highest post-partum heat period was observed in Beanibazar $(90.4 \pm$ $19.2)$ and lower $(80.7 \pm 21.3)$ days in Golapgong upazila. The days open was the highest $(107.5 \pm 27.4)$ in Companigong upazila and lower $(99.5 \pm 41.9)$ days in Golapgong $(\mathrm{p}>0.05)$. The cows in Kanaighat upazila showed longer calving interval $(417.4 \pm 110.4)$ compared with lowest $(395.1 \pm 54.6)$ days in Beanibazar upazila. The cows in Biswanath upazila needed the highest number of services per conception (1.54 \pm 0.9$)$, whereas the lowest $(1.27 \pm 0.7)$ was in Kanaighat upazila. Shamsuddin et al. (2006) investigated that the age at first calving was 37 months in Sirajgonj-Pabria, district while it was 40, 35 and 33 months for Mymensingh, Khulna-Satkhira and Chittagong, respectively.

In comparison of reproductive performances between metro and upazilas of Rajshahi district, we found all the traits of reproductive performances of dairy cows were higher value in upazilas than metro thanas, though a significant $(\mathrm{p}<0.05)$ difference was found only on service per conception between dairy cows of upazila and metro thanas and other reproductive traits were not significant $(\mathrm{p}>0.05)$. Weldeslasse et al. (2012) found that the high-grade exotic cows showed significantly $(\mathrm{p}<0.05)$ longer age at first calving, calving interval in peri-urban areas than urban areas but not on local breeds in Tigray, Northern Ethiopia. This better reproductive performance in metro thanas compared to upazilas may be due to better overall management, high quality feed supply, available of veterinary services and awareness program of farmers etc. Therefore, training and awareness creation and available of veterinary services should be given particularly to the upazila farmers to increase the reproductive and/or productive performances of the dairy cattle and livelihood of the dairy farmers through improved management practices.

\subsection{Reproductive disorders of dairy cows in Rajshahi district of Bangladesh}

The main constraint in the enhancement of dairy enterprises in Bangladesh is the low reproduction efficiency of dairy cows (Shamsuddoha and Edwards, 2000). Reproductive disorders have been found to be a major reason for decreased reproductive efficiency and of lifetime productivity (De-Vecchio et al., 1992). Very little is known about the extent of reproductive disorders in dairy cattle in Rajshahi district of Bangladesh. According to the results in the current study, a total of 500 adult cows were examined for the major reproductive problems by questionnaire survey. Out of these, $393(78.60 \%)$ were found to be affected by at least one of the reproductive problems, this is slightly higher than the findings of Kader (2010) who reported that $51.3 \%$ of dairy cattle in Bogra district of Bangladesh were affected with reproductive disorders. A $47.7 \%$ of dairy cows were having at least one of the reproductive problems observed by (Benti and Zewdie, 2014) in indigenous Borena breed cows in Borena zone in Southern Ethiopia. Contrasting to the resent finding, only $39.4 \%$ prevalence of reproductive diseases or disorders was reported in cross-bred dairy by (Alam et al., 2014) at Ullapara upazila under Sirajganj district. Haile et al. (2014) recorded $43.07 \%$ of cows were found to be affected either with one or more of reproductive problems. A $23.0 \%$ prevalence of reproductive diseases was reported in cross-bred cows in Chittagong district (Maruf, 2014). The variation in prevalence of reproductive diseases in cows in present study differ from others may be due to the differences in management (production) systems and environmental conditions, nutritional status, contamination during calving, and agro-climatic condition of the studied areas.

Anoestrus syndrome is the most important causes of infertility of dairy cows (Khan et al., 2016). In the present study, anoestrus $(24.6 \%)$ had the highest incidence among the reproductive disorders. Similarly, Al Nahian (2011) recorded the prevalence of anoestrus was 25.9\% in five Upazilas of Mymensingh district and observed the major reproductive disorders in cattle. (Shahabuddin, 1996) found the highest incidence $(22.97 \%)$ of anoestrus was in Panchagarh Veterinary Hospital, Panchagarh, Bangladesh. The recorded occurrence of anoestrus in the present study was higher than these values obtained by Khair et al. (2013), Sarder et al. (2010) and Kumar et al. (1986) which were $20.69 \%, 20.4 \%$, and 19\%, respectively. A higher incidence of anoestrus, even higher from the present study like $52 \%, 30.1 \%, 29.69 \%$ and $27.48 \%$ were recorded by Shamsuddin et al. (2007), Mahmud et al. (2014), Rahman et al. (1993) and Faruq (2001), respectively in their studies. These variations in the prevalence of anoestrus may be due to difference in the number of sample size, the influence of different risk factors such as nutritional status, management conditions, hormonal imbalance, and reproductive tract infections of cows, persistent corpus luteum etc. Lactation-induced reproductive inactivity varies among different species. Weaning followed by estrus and ovulation occur within 4 to 8 days in cow (Jainuddin and Hafez, 2000). Suckling and under nutrition, prevalent in surveyed area, inhibit the GnRH and LH secretion. Cessation of suckling in cows enhances the amount of LH release in response to LH-RH (Troxel et al., 1983).

In the present study about $11.4 \%$ cases found as repeat breeding cows, which agrees with the findings of $11 \%$, 12.8\%, and 13.08\% reported by Shamsuddin et al. (2007), Kader (2010) and Haile et al. (2014), respectively. 
The occurrence of repeat breeding was higher than these values obtained by Gizaw et al. (2007), Al Nahian (2011), Alam et al. (2014), which were $8.91 \%, 6 \%, 5.7 \%$, respectively and lower than $32.76 \%$, 26.8\%, and 15.9\% reported by Khair et al. (2013), Dinka (2013) and Esheti and Moges (2014), respectively. Mahmud et al. (2014) investigated the prevalence and comparison of reproductive diseases and disorders of cows and reported repeat breeding syndrome 35.5\% in BAU Vet. Clinic, Mymensingh and 15.7\% in Sadar Veterinary Hospital, Jamalpur, Bangladesh. Repeat breeder can be caused by a number of factors, including sub-fertile bulls, endocrine imbalance, malnutrition, reproductive tract infection and poor management practices such as wrong time of insemination or faulty heat detection, inappropriate semen handling and insemination techniques (Arthur et al., 1989). Jainuddin and Hafez (2000) also reported that incidence of repeat breeding is higher at artificial insemination rather than natural service. Poor quality semen, defective transportation of semen, unhygienic insemination are the main causes of repeat breeding syndrome in our country. Error in estrus detection and improper timing of AI, further aggravates the situation (Kumaresan, 2001). Anoestrus and repeat breeding syndrome are also the typical signs of non-specific subclinical uterine infection. The lack of proper hygienic management of post-partum cow and AI carried out without supervision of veterinary personnel predispose to such uterine infections. Our findings were unlike to earlier report of Rahman et al. (1993) who reported more incidence of repeat breeding syndrome than the anoestrus.

The prevalence rate of abortion $13.4 \%$ recorded by questionnaire survey in this study was almost similar to the findings of 13.9\%, 13.0\% and 12.2\% reported by Bitew and Prasad (2010), Molalegne and Shiv (2011) and Benti and Zewdie (2014), respectively. Dinka (2013) reported 14.6\% abortion in and around Asella town, Central Ethiopia. Higher percentage of abortion may be attributed due to differences in the etiology of abortion in respective regions and its agro-ecology that fairly favors the introduction and development of crossbred dairy cattle, where the problem is more common in exotics than local animals. Abortion is a frequent complication of brucellosis in animals, where placental localization is believed to be associated with erythritol, a growth stimulant for Brucella abortus (WHO, 2006). Moreover, abortion in cows may be influenced by infection and stress on animals (Bagley, 1999).

The prevalence of retained placenta was recorded $10.2 \%$ in the current study which is in line with those reported Benti and Zewdie (2014), Al Nahian (2011), and Islam et al. (2013). Mahmud et al. (2014) reported retained placenta $4.7 \%$ in BAU Vet. Clinic, Mymensingh and $17.9 \%$ in Sadar Vet. Hospital, Jamalpur, Bangladesh. Balasundaram (2008) reported $18.67 \%$ retained placenta in Karan Fries cow in India. The variation in the incidence of retained placenta may be attributed to variations in predisposing factors to which the animals are subjected and among which nutritional status and management are considered as important factor. The relatively higher prevalence rate of retained placenta in the present study could also be due to dystocia that accounted $5.4 \%$ which is an important predisposing factor for occurrence of retained placenta.

The prevalence of dystocia in this study was $5.4 \%$, which agrees with the findings of $5.8 \%$ and $6.6 \%$ reported by McDermott et al. (1992) and Bitew and Prasad (2010). This variation in the occurrence of dystocia may be influenced by factors such as age and parity of cows, breed and individual variations of sires (Morrow, 1986). Inseminating cows with semen collected from exotic bulls that genetically produce large sized calves without considering the size and age of cows often results in dystocia due to fetal over size. Bellows et al. (1996) recorded the incidence of dystocia was higher incidence in males than in females calves.

Among the infectious cause, pyometra and metritis were most frequently found in this study. During surveyed, it was observed that $1.8 \%$ cows showed pyometra and $1.6 \%$ of metritis. Similarly, Kader (2010) observed $1.7 \%$ cows showed pyometra and $1.5 \%$ of metritis in Bogra district. Pyometra can be caused by a number of factors, including Trichomonas foetus infection, unhygienic parturition, retained placenta, dystocia, vaginal prolapse and manual removal retained placenta. The lower prevalence of pyometra and metritis may be due to hygienic calving management, increasing awareness about retained placenta, dystocia and uterine prolapse. The incidence of various reproductive diseases especially uterine infections in the female, metritis and pyometra has increased alarmingly in this subcontinent with the introduction of cross breeding program among high yielding varieties of cows (Faruq, 2001; Khair et al., 2013). In addition to this, lack of on proper hygienic management of post-partum cows and limited veterinary service further aggravate the situation. It is suggested that in order to combat the occurrence of reproductive disorders in cows crossbreeding program through artificial insemination (AI) should be done proper hygienic management.

About $2.4 \%$ vaginal prolapse were observed which agrees with the findings of $2.2 \%$ and $2.7 \%$ reported by Sarder et al. (2010) and Alam et al. (2014), respectively. The prevalence of uterine prolapse was $1.4 \%$ in current study which is fairly agree with the findings of $1.3 \%, 1.4 \%$ and $1.6 \%$ obtained by Kader (2010), Sarder et al. (2010) and Alam et al. (2014). The lower prevalence rate of vaginal and uterine prolapse may be attributed to the available of calcium supply with feed and less chance to occurred hypocalcaemia. About $0.8 \%$ still birth was 
observed which was near to the findings of $1 \%$ and $1.03 \%$, reported by Kader (2010) and Haile et al. (2014), respectively. The productive disordered recorded in this study are $4.4 \%$ mastitis and $1.2 \%$ milk fever. Kader (2010) observed 6.6\% mastitis and 0.9\% milk fever in cows in Bogra district. The lower prevalence rate of mastitis may be resulted from increasing practice of hygienic milking, keeping the animal in hygienic milking shed in the study area where bio-security was maintained properly. This variation is also attributable to the time and place of study and breed of the cows as well as managemental and environmental factors.

The prevalence of reproductive disorders was also varied among upazilas and metro thansa of Rajshahi district. The highest prevalence of reproductive disorders was in Tanore upazila and the lowest in Poba upazila. In upazilas the higher occurrence $(47.6 \%)$ of reproductive disorders compared to metro thanas $(31 \%)$ recorded in the present study. The variation in the prevalence of reproductive problems among the different region may be due to effects of the differences in management (production) systems and environmental conditions including poor sanitation, nutritional status, contamination during calving, the insemination of animals with contaminated semen that may led to microbial infections of the uterine environment, which greatly affect the occurrence of reproductive problems.

\section{Conclusions}

The current investigation showed a relatively lower reproductive performance of dairy cows and higher incidence of reproductive health problems at upazila level compared to metro thanas in Rajshahi district of Bangladesh. The situation demands for further study to determine causes, economic impact and appropriate control strategies under different management systems. This study also clearly indicates that lack of awareness about performance of dairy cows and reproductive disorders among upazila farmers and their importance in the economic viability of their farms. Hence more efforts should be extended towards training, increasing awareness of the animal owners, available veterinary services about these problems and their proper management.

\section{Acknowledgements}

The author is very much grateful to dairy cows owners/farmers/attendant at study area for providing informations during study period. The author wants to express special thanks to Prime Minister Scholarship for funding the research work.

\section{Conflict of interests}

None to declare.

\section{References}

Ahmed F, GM Alam, AQ Al-Amin and CHB Hassan, 2013. The impact of climate changes on livestock sector: Challenging experience from Bangladesh. Asian J. Anim. Vet. Adv., 8: 29-40.

Al Nahian MZBR, 2011. Prevalence of reproductive disorders of cows in Mymensingh. MS Thesis. Department of Surgery and Obstetrics, Faculty of Veterinary Science, Bangladesh Agricultural University, Mymensingh, Bangladesh.

Alam MA, MMU Bhuiyan, MS Parvin, MM Rahman and FY Bari, 2014. Prevalence of reproductive diseases and its associated risk factors in crossbred dairy cows. Res. Agri. Livest. Fisheries., 1: 71-79.

Arthur GH, DE Noakes and H Pearson, 1989. Veterinary Reproduction and Obstetrics. Theriogenology $6^{\text {th }}$ (edn). Bailliere Tindall UK. pp. 83-85.

Azage T and G Alemu, 1998. Prospect for peri-urban dairy development in Ethiopia, Ethiopian Society of Animal Production (ESAP) Publication No.5. Addis Ababa, Ethiopia.

Bagley CV, 1999. Abortion in cattle. Utah State University Extension, Utah, USA. http://extension.usu.edu/ files/publications/factsheet/AH_Beef_36.pdf

Balasundaram B, 2008. Influence of genetic and non-genetic factors on incidence of reproductive disorders in cows. Ind. Vet. J., 110: 225-237.

Bellows RA, PC Genho, SA Moore and CC Chase, 1996. Factors affecting dystocia in Brahman-cross heifers in subtropical southeastern United States. J. Anim. Sci., 74: 1451-1456.

Benti AD and W Zewdie, 2014. Major reproductive health problems of indigenous Borena cows in Ethiopia. J. Adv. Vet. Anim. Res., 1: 182-188.

BER (Bangladesh Economic Review), 2014. Bangladesh Economic Review. Government of the People's Republic of Bangladesh. Finance Division. Ministry of Finance (MoF), Dhaka, Bangladesh.

Bitew M and S Prasad, 2010. Study on major reproductive health problems in indigenous and cross breed cows in and Around Bedelle, South West Ethiopia. J. Anim. Vet. Adv., 10: 723-727. 
Carew SF, J Sandford, YJ Wissocq, J Durkin and JCM Trail, 1986. N'Dama cattle productivity at Tako Livestock Station, Sierra Leone and initial results from crossbreeding with Sahiwal. International Livestock Centre for Africa Bulletin., 23:1-10.

Das SC, MA Rahman, JU Ahmed and MGS Alam, 1995. Reproductive disorders in zebu cows of Tangail milk shed area. Bd. J. Anim. Sci., 24: 19-25.

De-Vecchio RP, DJ Matsas, TJ Inzana, DP Sponenberg and GS Lewis, 1992. Effects of intrauterine bacterial infusions and subsequent endometritis on prostaglandin F2 $\alpha$ Metabolites concentration in post-partum beef cows. J. Anim. Sci., 70: 3158-3162.

Dinka H, 2013. Major reproductive disorders of dairy cows in and around Asella town, Central Ethiopia. J. Vet. Med. Anim. Healt., 5:113-117.

Ensminger ME, 1969. Animal science. Interstate Printers and Publishers, Danville, Illinois, USA. p. 1253.

Esheti G and N Moges, 2014. Major reproductive health disorders in cross breed dairy cows in Ada'a District, East Shoa, Ethiopia. Global Veterinaria., 13:444-449.

FAO (Food and Agriculture organization), 2005. Livestock policy recommendation for the Government of Bangladesh Initial finding for discussion, Technical co-operation programme, FAO regional office for Asia and Pacific, Bangkok., 4-13.

FAO (Food and Agriculture organization), 2009. Livestock, food security and poverty reduction. http://www.fao.org/docrep/012/i0680e/i0680e03.pdf

Faruq MBH, 2001. Clinical and abattoir studies on reproductive diseases of cows in Bangladesh. MS Thesis. Department of Surgery and Obstetrics, Faculty of Veterinary Science, Bangladesh Agricultural University, Mymensingh, Bangladesh.

Gizaw Y, M Bekana and T Abayneh, 2007. Major reproductive health problems in smallholder dairy production in and around Nazareth town, Central Ethiopia. DVM thesis. Faculty of Veterinary Medicine, Addis Ababa University, Debre Zeit, Ethiopia.

Grohn YT and PJ Rajawala, 2000. Epidemiology of reproductive performance in dairy cows. Anim. Reprod. Sci., 60: 605-614.

Haile A, Y Tsegaye and N Tesfaye, 2014. Assessment of major reproductive disorders of dairy cattle in urban and per urban area of Hosanna, Southern Ethiopia. Anim. Vet. Sci., 2: 135-141.

Hoque MA, MR Amin and MS Lessen, 1999. Dairy potential of Pabna cows and crossbred with Sahiwal and Friesian and within and between breed sire effects. Asian-Australian J. Anim. Sci., 12: 161-164.

Hossain MA, 2013. Evaluation of reproductive performances of cows at different upazilas in Sylhet district. MS in Theriogenology Thesis, Department of Surgery and Obstetrics, Faculty of Veterinary Science, Bangladesh Agricultural University, Mymensingh, Bangladesh.

Islam MH, MJU Sarder, SS Jahan, M Rahman, M Zahan, MA Kader and KMM Hossain, 2013. Retained placenta of dairy cows associated with managemental factors in Rajshahi, Bangladesh, Vet. World., 6: 180-184.

Jainudden MR and ESE Hafez, 2000. Cattle and Buffalo. In: Reproduction in Farm Animals. Edited by E.SE. Hafez. Lea \& Febriaer, Philadelphia. pp. 164-167.

Kader MA, 2010. Prevalence of reproductive diseases of cows at Bogra district in Bangladesh. MS Thesis, submitted to the Department of Animal Husbandry and Veterinary Science, Faculty of Agriculture, University of Rajshahi, Bangladesh.

Khair A, MM Alam, AKMA Rahman, MT Islam, A Azim and EH Chowdhury, 2013. Incidence of reproductive and production diseases of cross-bred dairy cattle in Bangladesh. Bd. J. Vet. Med., 11: 31-36.

Khan MH, K Manoj and P Pramod, 2016. Reproductive disorders in dairy cattle under semi-intensive system of rearing in North-Eastern India. Vet. World., 9: 512-518.

Kumar S, SK Agarwal and LN Purbey, 1986. Studies on reproductive disorders in non- descript cattle. Ind. Vet. Med. J., 10: 174-175.

Kumaresan A, 2001. Repeat breeding syndrome in cattle and buffaloes; therapeutic approach at field level. Pashudhan., 16: 4.

Levine HD, 1999. The repeat breeder cow. The Bovine Practitioner., 33: 97-105.

Mahmud MK, MK Rahman, AA Maruf, ASM Sayam, MA Mutaleb, MI Ali and MA Habib, 2014. Prevalence of reproductive diseases and disorders in cows and goats recorded in two Veterinary hospitals in Bangladesh. Amer. Res. Thot., 1: 285-303.

Maruf AA, AK Paul, N Bonaparte, MH Bhuiyan and M Shamsuddin, 2014. Reproductive disorders that limit the reproductive performance in dairy cows of Bangladesh. J. Embryo Tfr., 29: 189-194.

McDermott JJ, OB Allen, SW Martin and DM Alves, 1992. Patterns of stillbirth and dystocia in Ontario cowcalf herds. Canadian J. Vet. Res., 56: 47-55. 
MoEF, 2009. Climate change, adaptation plan of action, 2009. Ministry of Environment and Forest, Government of Bangladesh, Bangladesh.

Molalegne B and P Shiv, 2011. Study on major reproductive health problems in indigenous and cross breed cows in and Around Bedelle, South West Ethiopia. J. Anim. Vet. Adv., 10: 723-727.

Morrow DA, 1986. Diagnosis, treatment and prevention of reproductive diseases in animals. In: Current Therapy in Theriogenology. W.B. Soundars Company, Philadelphia. pp. 322-571.

Morton JM, 2003. Identifying risk factors for reproductive performance in Australian dairy herds. Cattle Practices., 11: 201-208.

Mureda E and ZM Zeleke, 2008. Characteristics and constraints of crossbred dairy cattle production in lowland areas of Eastern Ethiopia. Livestock Research for Rural Development. Volume 20, Article \#57. Retrieved on March 14, 2016, from http://www.lrrd.org/lrrd20/4/mure20057.htm.

Nahar TN, M Islam and MA Hasnath, 1992. A comparative study on the performance of F cross-bred cows under rural condition. Asian-Australian J. Anim. Sci., 5: 435-438.

Radostits OM, CC Gay, KW Hinchliff and PD Constable, 2006. Veterinary Medicine: A textbook of the diseases of cattle, horses, sheep, pigs and goats. 10 ${ }^{\text {th }}$ edition, W.B. Saunders Co., Philadelphia., pp. 673-748.

Rahman MF, MS Hossain and MAM Prodhan, 1993. Reproductive problems of cattle in Bangladesh. Bangladesh Veterinarian, 10: 71-73.

Santos JEP, 2007. Implementation of reproductive programs in dairy herds: Nottingham cattle fertility conference, $4^{\text {th }}$ September, 2007. Leicestershir,. p. 1-9.

Sarder MJU, MIZ Moni and S Aktar, 2010. Prevalence of reproductive disorders of cross breed cows in the Rajshahi district of Bangladesh. SAARC J. Agri., 8: 65-75.

Sarder MJU, 2001. Reproductive and productive performance of indigenous cows. Bangladesh. Veterinarian., 18: $123-129$.

Sarma PK and JU Ahmed, 2011. An economic study of small scale cattle fattening enterprise of Rajbari district. J. Bd. Agri. Uni., 9: 141-146.

Shahabuddin M, 1996. Pathological disorders encountered in female reproductive system of cattle. MS Thesis. Department of Pathology, Bangladesh Agricultural University, Mymensingh, Bangladesh.

Shamsuddin M, MGS Alam and JU Ahmed, 1988. Reproductive disorders of crossbred cows. Bd. Vet. J., 22: 21-28.

Shamsuddin M, MMU Bhuiyan, TK Sikder, AH Sugulle, PK Chandra and MGS Alam, 2001. Constraints limiting the efficiency of artificial insemination of cattle in Bangladesh. Int. Atom. Erg. Agcy., 1220: 9-27.

Shamsuddin M, WE Goodger, MS Hossein, BT Azizunnesa, and K Nardlund, 2006. A survey to identify economic opportunities for smallholder dairy farms in Bangladesh. Trop. Anim. Healt. Prod., 38: 131-140.

Shamsuddin M, MS Hossein, MAR Siddiqui, AHMSI Khan, FY Bari, MF Alam, M Rahman, ASM Sayem and $\mathrm{H}$ Momont, 2007. Use of milk progesterone radioimmunoassay and computer applications for community based reproductive health services in small holder dairy farms of Bangladesh. Improving the reproductive management of dairy cattle subjected to artificial insemination. IAEA (International Atomic Energy Agency), Vienna, Austria. pp. 9-22.

Shamsuddoha AK and G Edwards, 2000. Dairy Industry in Bangladesh: Problems and Prospects. $44^{\text {th }}$ AARES (Australian Agricultural and Resource Economics Society) Conference, Sydney, Australia. 23-25 January 2000.

Talukder MAS, MAMY Khandoker, MGM Rahman, MR Islam and MAA Khan, 2005. Reproductive problems of cow at Bangladesh Agricultural University Dairy Farm and possible remedies. Pak. J. Bio. Sci., 8: 15611567.

Troxel TR, GF Cmarik, RS Ott, TF Lock and DJ Kesler, 1983. The effect of method of GnRH and short-term calf removal on ovarian function and reproductive performance in post-partum suckled beef cows administered $\mathrm{PGF}_{2 \alpha}$ for estrus synchronization. Theriogenology, 20: 417.

Vacek M, L Stadnik and M Stipkova, 2007. Relationships between the incidence of health disorders and the reproduction traits of Holstein cows in the Czech Republic. Czech J. Anim. Sci., 52: 227-235.

Weldeslasse GT, ZM Zeleke and SK Gangwar, 2012. Reproductive and productive performance of dairy cattle in central zone of Tigray, Northern Ethiopia. Int. J. Adv. Biol. Res., 2: 58-63.

WHO (World Health organization), 2006. Brucellosis in Humans and Animals. WHO Press, 20 Avenue Appia, Geneva, Switzerland. 